\title{
Evaluation of Short-Term Fish Reproductive Bioassays for Predicting Effects of a Canadian Bleached Kraft Mill Effluent
}

\author{
Michael R. van den Heuvel, ${ }^{1 *}$ Pierre H. Martel, ${ }^{2}$ Tibor G. Kovacs, ${ }^{2}$ \\ Deborah L. MacLatchy, ${ }^{3,4}$ Glen J. Van Der Kraak, ${ }^{5}$ Joanne L. Parrott, ${ }^{6}$ Mark E. McMaster, ${ }^{6}$ \\ Brian I. O’Connor, ${ }^{2}$ Steven D. Melvin, ${ }^{4}$ L. Mark Hewitt ${ }^{6}$ \\ ${ }^{1,3,4}$ Canadian Rivers Institute: ${ }^{1}$ Department of Biology, University of Prince Edward Island, 550 University \\ Avenue, Charlottetown, Prince Edward Island; ${ }^{3}$ Wilfrid Laurier University, Waterloo, Ontario; ${ }^{4}$ University of New \\ Brunswick, Saint John, New Brunswick, Canada \\ ${ }^{2}$ FPInnovations - Paprican Division, Pointe-Claire, Canada \\ ${ }^{5}$ University of Guelph, Guelph, Ontario, Canada \\ ${ }^{6}$ Environment Canada, Burlington, Ontario, Canada
}

\begin{abstract}
Under the Canadian Environmental Effects Monitoring (EEM) program for pulp and paper effluents, the observation of a national response pattern of decreased gonad size and increased fish condition and liver size has triggered a centralized multiagency investigation of cause (IOC) of reproductive impacts in fishes. The purpose of the component of the IOC study presented here is to compare a number of fish bioassays for determining reproductive and reproductive-endocrine effects of a bleached kraft mill effluent. The bleached kraft mill chosen for this study had demonstrated the national response pattern in previous EEM cycles. The bioassays employed to examine reproduction were fathead minnow (Pimephales promelas) 5- and 21-d, mummichog (Fundulus heteroclitus) 25-d, and zebrafish (Danio rerio) 7-d tests, all of which had egg production as the primary reproductive endpoint. Additional bioassays examining reproductive-endocrine endpoints included a 7-d mummichog test, a 7- and a 21-d threespine stickleback (Gasterosteus aculeatus) test, a rainbow trout (Oncorbynchus mykiss) 7-d test, and in vitro sex steroid receptor and plasma protein binding bioassays. The zebrafish and fathead minnow reproductive tests showed significant suppression of egg production at the $100 \%$ effluent concentration. Endocrine data derived from the tests showed that this effluent did not impact steroidogenic endpoints at any concentration. Bioassays showed that this effluent i) was capable of eliciting cytochrome P4501A induction at as low as $10 \% \mathrm{vol} / \mathrm{vol}$ effluent, ii) was weakly androgenic at $10 \%$ $\mathrm{vol} / \mathrm{vol}$, and iii) showed no evidence of in vivo estrogenicity. These results were consistent with in vitro receptor binding assays showing a highly variable level of androgenic equivalents over six months of effluent testing, with little evidence of estrogenic activity. Bioassay results were consistent in that the overall conclusion was that this effluent has only a weak potential to cause reproductive impairment and would likely not do so at environmentally relevant concentrations. Field studies and a fathead minnow lifecycle study conducted concurrently were in agreement with reproductive bioassay results as white sucker exposed in the receiving environment no longer had significantly reduced gonadal development. Overall, this study provided evidence that the laboratory assays evaluated for various reproductive endpoints have potential application for future IOC work.
\end{abstract}

Key words: fish, reproduction, egg production, pulp and paper, effluent, recovery

\section{Introduction}

In 1992, the regulations pertaining to the discharge of pulp and paper mill effluents were revised in Canada. In addition to stricter control for the discharge of biochemical oxygen demand (BOD), total suspended solids, and acute lethality, the revised regulations included the establishment of the Environmental Effects Monitoring (EEM) program. A component of EEM examines the effects of pulp and paper effluents on wild fishes. The aim of the EEM program is to use the information from the study of wild fish to assess the adequacy of the discharge regulations on a site-specific basis. The first three cycles of the EEM program showed that pulp and paper mill

\footnotetext{
*Corresponding author; mheuvel@upei.ca
}

effluents were causing a eutrophication response in the receiving environment as well as a national pattern of metabolic disruption in fishes (Lowell et al. 2005).

Metabolic disruption, a term given to a pattern of reduced gonadal development associated with greater energy storage in liver and body tissue (Gibbons and Munkittrick 1994), has been a longstanding observation in wild fish populations exposed to pulp and paper mill effluents (Munkittrick et al. 1994). Reduced gonad growth has been associated with a reduction in circulating sex steroid hormones (Munkittrick et al. 1994) and reduced in vitro steroid hormone production in white sucker (Catostomus commersoni) (Van Der Kraak et al. 1992). While exposure to androgens (Ellis et al. 2003), estrogens (van den Heuvel and Ellis 2002), and CYP1A- (cytochrome P4501A-) inducing compounds (Hodson et al. 1992; Munkittrick et al. 
1994) have also been frequently demonstrated; there has been no clear mechanistic linkage between specific compounds and impacts observed in wild fishes. When effects in EEM studies at individual mill sites are evident for two consecutive cycles, the EEM program calls for Investigation of Cause (IOC) and Investigation of Solution (IOS) studies so that the cause(s) of effects can be determined and so effects can be reduced or entirely eliminated. However, protocols for IOC and IOS studies were not readily available and, as such, a multiagency team was assembled to undertake pilot studies as part of a centralized National IOC Project in Canada.

The first activity of the IOC consortium was a review of the international literature in order to determine if reproductive effects observed in wild fish populations could be linked to mill processes, treatment types, or individual compounds (Hewitt et al. 2008). It was concluded that fishes exposed to the effluent of mills of all manufacturing process types can exhibit reproductive impacts. Where improvement or recovery has occurred, a variety of factors have been implicated such as installation or improved biological treatment, reduction of the release of pulping liquors to the effluent stream, and chlorine dioxide substitution for bleaching of kraft pulps. Thus, despite much work conducted to date, international research remains ambiguous with regards to specific causes and solutions. The review further concluded that for future progress in identifying remedial strategies, the selection or development of cost-effective investigative tools was needed.

Subsequently, the focus of the National IOC Project for reproductive impacts on fishes was on the selection and/or development of diagnostic tools that could be used for IOC/IOS work. One of the first objectives of this work was to comprehensively evaluate existing shortterm reproductive tests that are practical for identifying causal agents but are also predictive of metabolic disruption in wild fishes (Hewitt et al. 2008). A bleached kraft mill located on the St. Maurice River in La Tuque, Quebec was selected for initial study because it exhibited reduced gonad size in previous studies (Gagnon et al. 1995), and continued to exhibit a metabolic disruption response pattern in its most recent EEM cycles (Tessier et al. 2009).

The present study tested effluent from the La Tuque mill in a suite of different reproductive bioassays in order to assess their ability to detect reproductive effects that could be linked to gonad size changes in wild fishes captured in the mill receiving environment (Parrott et al. 2010). The primary short-term reproductive endpoints compared in the present study were mummichog (Fundulus heteroclitus) egg production, fathead minnow (Pimephales promelas) egg production, and zebrafish (Danio rerio) egg production. These bioassays were supplemented by a number of suborganism endpoints to examine endocrine reproductive function including measures of steroidogenic capacity in mummichog, threespine stickleback (Gasterosteus aculeatus), and zebrafish, as well as indicators of exposure to androgens, estrogens, and CYP1A-inducing compounds.

\section{Materials and Methods}

\section{Mill and Effluent Collection}

The mill selected for this study produced bleached (DNED, $\mathrm{DED} ; \mathrm{D}=$ chlorine dioxide, $\mathrm{E}=$ alkaline extraction, $\mathrm{N}=$ nitrogen compounds) kraft pulp for about $1,200 \mathrm{t} / \mathrm{d}$ of linerboard, paperboard, and foodboard. The products are made from $40 \%$ chips $(23 \%$ softwood chips, $17 \%$ hardwood chips) and sawdust/shavings (mainly softwood). The process water usage at the mill was $87,000 \mathrm{~m}^{3} / \mathrm{d}$. The mill effluent was treated in an oxygenactivated sludge plant, with a hydraulic retention time of about $9.8 \mathrm{~h}$, prior to discharge into the St. Maurice River, Quebec (approximately 1\% [vol/vol] in the river). Between June and December, 2006, final effluent grab samples were taken from the treatment system outfall by mill staff directly into 1,000-L food-grade plastic totes. Transport times ranged from 1 to $3 \mathrm{~d}$ and testing was begun immediately upon receipt of the effluent.

\section{Experimental Overview}

Tests conducted were classified to be reproductive bioassays where some measure or reproductive output was quantified (e.g., egg production), or were considered to be reproductive-endocrine bioassays where other reproductive parameters were measured (e.g., steroid hormones: see details of all bioassays in Table 1). Reproduction was directly assessed in three species: fathead minnow, mummichog, and zebrafish. In fathead minnow, two time durations were used in order to validate the use of a shorter-term test. The 21-d fathead minnow test is herein defined as medium-term, while the 7-d test is referred to as short-term. Three species were chosen for reproductive endocrine bioassays, rainbow trout (Oncorhynchus mykiss), threespine stickleback, and mummichog (Table 1).

All tests were conducted in flow-through systems with the exception of the zebrafish and rainbow trout tests, which were static with daily renewal. Concentrations for bioassays were chosen to be 0 (diluent water), 1, 10, 30, and $100 \% \mathrm{vol} / \mathrm{vol}$ effluent. The exceptions to this were for the zebrafish bioassay where $65 \% \mathrm{vol} / \mathrm{vol}$ effluent was substituted for $100 \%$, and the stickleback bioassay that did not have a $30 \%$ concentration. All flow-through and static exposures had between one and four tank turnovers per day. Fish loading rates varied with the bioassay used and ranged from 0.33 to $3.69 \mathrm{~g} / \mathrm{L} / \mathrm{d}$. Dissolved oxygen was maintained at $>75 \%$ saturation for all treatments in all bioassays. 
Reproductive Bioassays for the Effects of BKME

TABLE 1. Summary of reproductive and reproductive-endocrine tests conducted for the IOC study with La Tuque mill effluent

\begin{tabular}{|c|c|c|c|}
\hline Test organism/bioassay & $\begin{array}{l}\text { Date effluent } \\
\text { sampled } \\
\text { in } 2006\end{array}$ & $\begin{array}{l}\text { Effluent } \\
\text { exposure } \\
\text { duration }\end{array}$ & Endpoints \\
\hline \multicolumn{4}{|l|}{ REPRODUCTION BIOASSAYS } \\
\hline Fathead minnow medium-term & $\begin{array}{l}\text { May } 30 \\
\text { June } 13 \\
\text { June } 16\end{array}$ & $21 \mathrm{~d}$ & $\begin{array}{l}\text { Gonad size, egg production, number of spawns, egg fertilization, } \\
\text { egg hatching, secondary sexual characteristics, VTG, plasma } \\
\text { steroid hormones }\end{array}$ \\
\hline Fathead minnow short-term & September 5 & $5 \mathrm{~d}$ & Gonad size, egg production, number of spawns, egg fertilization \\
\hline Mummichog & May 30 & $\begin{array}{r}18 \mathrm{~d}^{a} \\
7 \mathrm{~d}^{b}\end{array}$ & $\begin{array}{l}\text { Egg production, number of spawns, egg fertilization, gonad size, } \\
\text { hatching success, juvenile survival }\end{array}$ \\
\hline Zebrafish & July 3 & $7 \mathrm{~d}$ & $\begin{array}{l}\text { Egg production, number of spawns, expression of StAR, } \\
\text { aromatase, } 3 \beta-H S D \text {, whole body steroids, and VTG }\end{array}$ \\
\hline \multicolumn{4}{|c|}{ REPRODUCTIVE ENDOCRINE BIOASSAYS } \\
\hline Mummichog & May 30 & $7 \mathrm{~d}$ & Plasma sex steroids \\
\hline Rainbow trout & June 13 & $7 \mathrm{~d}$ & Whole body VTG \\
\hline Threespine stickleback & December & $21 \mathrm{~d}$ & In vitro steroidogenesis, spiggin mRNA, VTG mRNA \\
\hline
\end{tabular}

${ }^{a} 18$-d effluent preexposure.

${ }^{b} 7$-d reproductive assessment.

\section{Fathead Minnow Tests}

Fathead minnow were held in well water at $25^{\circ} \mathrm{C}$ with a photoperiod of 16-h light and 8-h dark, and were fed three times daily with frozen brine shrimp, commercial trout food, or fish flakes. The mean (and standard deviation [SD]) weights of fathead minnows used during the exposure were $5.2(0.3)$ and $2.3(0.2) \mathrm{g}$ for males and females, respectively. The short-term and medium-term tests were adaptations of a test developed by Ankley et al. (2001) and have been used for previous work with mill effluents (Martel et al. 2004; Kovacs et al. 2007). For the preexposure phase, the fish were distributed in groups of two males and four females into aquaria containing two spawning substrates. The effluent-exposure phase of the tests was initiated by selecting groups of fish that produced 18 or more eggs per female per day and had three or more spawning events over seven days during the preexposure phase. These groups were randomly assigned to one of the four replicates for each of the five treatments.

Fish and tanks were monitored for the number of spawns, and egg production and egg fertilization were also assessed. Hatching success of the eggs was only monitored in the medium-term test. At the end of the tests, each fish was examined for secondary sexual characteristics using criteria described earlier (Martel et al. 2004). The rest of the fish (including head, tail, and internal viscera except for gonads) were homogenized and assayed for testosterone (males and females), estradiol (females), and vitellogenin activity (males) as described previously (Martel et al. 2004). Water quality was measured daily and the range of temperature was 24 to $26^{\circ} \mathrm{C}$, and $\mathrm{pH}$ ranged from 7.4 to 8.5 .

\section{Mummichog Tests}

Adult mummichog were collected in May 2006 from Shediac Bay, New Brunswick with a beach seine.
The mean (SD) weights of mummichog used in the experiments were $8.7(0.6)$ and $10.4(0.5) \mathrm{g}$ for males and females, respectively. Fish were maintained in holding tanks maintained at $16 \%$ salinity, 18 to $20^{\circ} \mathrm{C}$, $>85 \%$ oxygen, and a natural photoperiod. Fish were fed standard trout pellets (Corey Aquafeed, Fredericton, N.B.) twice daily to satiation. Effluent concentrations were adjusted to $16 \%$ salinity during the exposure. In the reproductive-endocrine mummichog test, adult males and females were exposed for $7 \mathrm{~d}$ to determine effects on the reproductive endocrine system. The endpoints included plasma testosterone and 11-ketotestosterone in males and plasma testosterone and estradiol in females, and were measured using an increased precision radioimmunoassay (RIA) for analyzing small plasma volumes $(20$ to $50 \mu \mathrm{L}$ ) (MacLatchy et al. 2005). Water temperature ranged from 17 to $21^{\circ} \mathrm{C}$, and $\mathrm{pH}$ from 7.0 to 8.0 across all exposure concentrations.

In the reproductive test, males and females were separately exposed to effluent for $18 \mathrm{~d}$ and were then combined in aquaria for $7 \mathrm{~d}$ to assess reproductive performance. There were twelve control aquaria and six replicates of all effluent concentrations, each containing 3 males and 3 females. A mesh cage was placed within each aquarium, 2 to $3 \mathrm{~cm}$ above the bottom, allowing eggs to fall to the bottom but preventing the adults from consuming them. Eggs were collected by dredging the tank with a fine dip net.

After collection, eggs were placed into Petri dishes at a density of 40 eggs per dish and exposure concentrations were replaced manually in each dish once a day until the eggs hatched. Eggs were visually inspected daily for development of cleavage and any unfertilized or dead eggs were removed. Upon hatching, larvae were transferred to $50-\mathrm{mL}$ beakers containing the appropriate exposure concentrations at a density of 10 larvae per beaker. Fish were monitored for yolk sac absorption and were returned to the original test aquaria (containing 5 L of appropriate treatment) when the yolk sac was fully 
absorbed and swimming had commenced. Larvae were fed brine shrimp (Artemia sp. nauplii) twice daily, and fry food once daily (Rolf C. Hagen, Montreal, Que.) ad libitum. Growth was monitored for six weeks by taking average length measurements from 20 fish in each tank.

\section{Zebrafish Tests}

Adult zebrafish were received from DAP International (Etobicoke, Ont.). Fish were held in A-HAB units (Aquatic Habitats, Apopka, Fla.) at $28^{\circ} \mathrm{C}$ in an environmental chamber. Fish were maintained in recirculated well water with a 12-h light and 12-h dark photoperiod. The mean (SD) weight of zebrafish used in the experiments was $0.46(0.11) \mathrm{g}$. Fish were fed to satiation two to three times per day with a combination of commercial salmon fry formulation (Martin Mills, Elmira Ont.) and frozen blood worms (Oregon Desert Brine Shrimp Co., Lakeview Oreg.).

Sexually mature adult zebrafish were visually sexed and two male and two female zebrafish were housed in individual static breeding containers with $1 \mathrm{~L}$ of well water. These vessels consisted of two plastic containers stacked together. The bottom of the top container was replaced with a mesh so that spawned eggs would fall through and be separated from the fish until collection. Each treatment contained six breeding containers that were placed in a random order in large water baths at $28^{\circ} \mathrm{C}$ and fish were held in experimental conditions for the 7-d preexposure period. Fish were then exposed for 7 days to pulp mill effluent diluted in well water or well water alone. Water quality was monitored daily and temperature ranged from 26 to $29^{\circ} \mathrm{C}$ and $\mathrm{pH}$ ranged from 7.0 to 8.0 across all treatments.

Eggs were removed by siphoning the breeding containers with a Pasteur pipette and counted. At the end of the exposure, fish were overdosed with MS-222 (Sigma, St. Louis Mo.) and weighed. Ovaries from fish in each breeding container were weighed and stored in RNALater (Ambion, Austin Tex.) at $4^{\circ} \mathrm{C}$ until separation into primary growth, previtellogenic, and vitellogenic follicle stages by follicle size prior to RNA extraction. Fish carcases were snap frozen in liquid nitrogen and stored at $-80^{\circ} \mathrm{C}$ prior to extraction of steroids. RNA extraction, reverse transcription, and Real-Time PCR (polymerase chain reaction) followed the methods described by Ings and Van Der Kraak (2006). The genes evaluated included steroid acute regulatory protein (StAR), P450-aromatase A (P450-arom), and 3 $\beta$-hydroxysteroid dehydrogenase (3ß-HSD).

\section{Rainbow Trout Tests}

Immature rainbow trout were used in a 7-d test to measure levels of whole body vitellogenin (VTG) and liver 7-ethoxyresorufin-O-deethylase (EROD). The fish were exposed in $15-\mathrm{L}$ containers for $7 \mathrm{~d}$. Temperature ranged from 12 to $13^{\circ} \mathrm{C}$ and $\mathrm{pH}$ ranged from 7.1 to 8.6 across the treatments. At the end of the exposure period, the trout were weighed, homogenized in a phosphate buffer containing gelatin at $4^{\circ} \mathrm{C}$, and centrifuged at 3100 $\mathrm{g}$ for $10 \mathrm{~min}$. The resulting supernatants were stored at $-85^{\circ} \mathrm{C}$ until analysis with the rainbow trout vitellogenin enzyme immunoassay kit from Biosense Laboratories (Bergen, Norway). All samples were assayed in duplicate. Hepatic EROD was estimated in postmitochondrial supernatant as an indicator of exposure to hydrocarbons in the effluent. EROD activity was determined using a modification of the fluorescence plate-reader technique outlined by van den Heuvel et al. (1995).

\section{Stickleback Tests}

Tests with stickleback were to assess exposure to androgens or estrogens in vivo, and methods are published elsewhere (Hogan et al. 2008; Wartman et al. 2009). The mean (SD) weights of stickleback used in the experiments were $1.54(0.56)$ and $1.27(0.35) \mathrm{g}$ for females and males, respectively. Endpoints presented herein are in vitro steroidogenesis, posterior kidney spiggin mRNA production in females, liver VTG mRNA abundance in males, and receptor-binding potency of effluent extracts using rainbow trout brain androgen receptor (AR) and rainbow trout liver estrogen receptor (ER) bioassays.

\section{Effluent Chemistry}

Effluent samples collected for the short- and medium-term fathead minnow reproduction tests were qualitatively characterized by solid phase microextraction (SPME) using a commercially available apparatus (Supelco). Samples $(10 \mathrm{~mL})$ of each effluent were transferred to inert Teflon vessels and stirred at a constant rate with Teflon coated micro stir bars. The SPME fibre with a $100-\mu \mathrm{m}$ polydimethylsiloxane coating was immersed in the effluent sample for $60 \mathrm{~min}$ at room temperature (approximately $22^{\circ} \mathrm{C}$ ). The loaded fibres were analyzed by full scan (m/z 50 to 500) gas chromatography/mass spectrometry (GC/MS) using an Agilent 6890 Series GC coupled with a 5973 mass selective detector. The samples were desorbed in the injection port in splitless mode for 1.5 min at $250^{\circ} \mathrm{C}$. The chemical components were separated on a $30-\mathrm{m}$ by $0.25-\mathrm{mm}(0.25-\mu \mathrm{m}$ film thickness) DB-5MS capillary column (J\&W Scientific) using a helium carrier flow rate of $1.3 \mathrm{~mL} / \mathrm{min}$. The oven temperature program began at $50^{\circ} \mathrm{C}$ for $5 \mathrm{~min}$ followed by a $5^{\circ} \mathrm{C}$ per minute increase to $260^{\circ} \mathrm{C}$ and a final hold of 13 minutes. Total peak areas were normalized to the lowest value to obtain a relative index of effluent strength.

\section{Binding Assays for Goldfish AR and Sex Steroid Binding Protein (SSBP)}

During each week from July to December, effluent samples for binding assays were collected in plastic bottles and stored frozen until lyophilization. For each month, two of the weekly samples were randomly selected for 
lyophilization; these were then pooled to generate a sample representative for that month. Lyophilized residues were weighed and subsequently soxhlet extracted sequentially for $12 \mathrm{~h}$ using dichloromethane followed by methanol. Extracts were rotary-evaporated and reduced to just dryness using a gentle stream of nitrogen and brought up to standardized concentrations of effluent volume equivalents in dimethylsulfoxide for incubations with the goldfish testicular AR and plasma SSBP as described in detail in Hewitt et al.(2000). The results of each binding assay are presented as effluent concentrations of androgen equivalents, obtained by interpolating competitive extract displacements with accompanying testosterone standard curves. Appropriate laboratory blanks were prepared in parallel with effluent samples and did not differ from the dimethylsulfoxide carrier controls.

\section{Statistics}

All statistical comparisons were made at the 5\% significance level $(p<0.05)$. When necessary, the data were $\log$ transformed to meet assumptions of normality and homogeneity. When the data met assumptions of normality and homogeneity, the mean eggs produced per female per day, number of spawns, percentage fertilization, and percentage hatching from fertilized eggs were compared for significant differences by analysis of variance (ANOVA) with the aquarium being the experimental unit of replication. Where the design allowed, parameters were compared for significant differences using an ANOVA model with aquaria as a nested factor within treatments. For gonad weight, a covariate of body weight was added. In cases when the ANOVA indicated a significant effluent-related effect, Dunnett's test or the Least Significant Difference test was used to identify the specific effluent concentrations that were statistically significantly different from the control.

\section{Results}

The mill effluent tested was not acutely lethal at any of the bioassay concentrations tested. Mortalities for females in the 21-d fathead minnow bioassay were $6.25 \%$ mortality in control, $1 \%$, and $30 \%$ effluent concentrations, and $12.5 \%$ in $100 \%$ effluent. For males, mortality was $12.5 \%$ in the 1 and $100 \%$ effluent concentrations. During the spawning portion of the mummichog reproductive test, mortalities were $0 \%$ in the $1 \%$ effluent concentration, $16 \%$ in the 10 and $100 \%$ effluent concentrations, and $25 \%$ in the control and $30 \%$ effluent concentration due to sea lice infestation. In the zebrafish bioassay, only one male mortality was observed and this occurred in the $30 \%$ effluent group $(4 \%)$.

Egg production in fathead minnow exposed to $100 \%$ effluent for $21 \mathrm{~d}$ was found to be significantly decreased compared with controls (Fig. 1 and 2). The
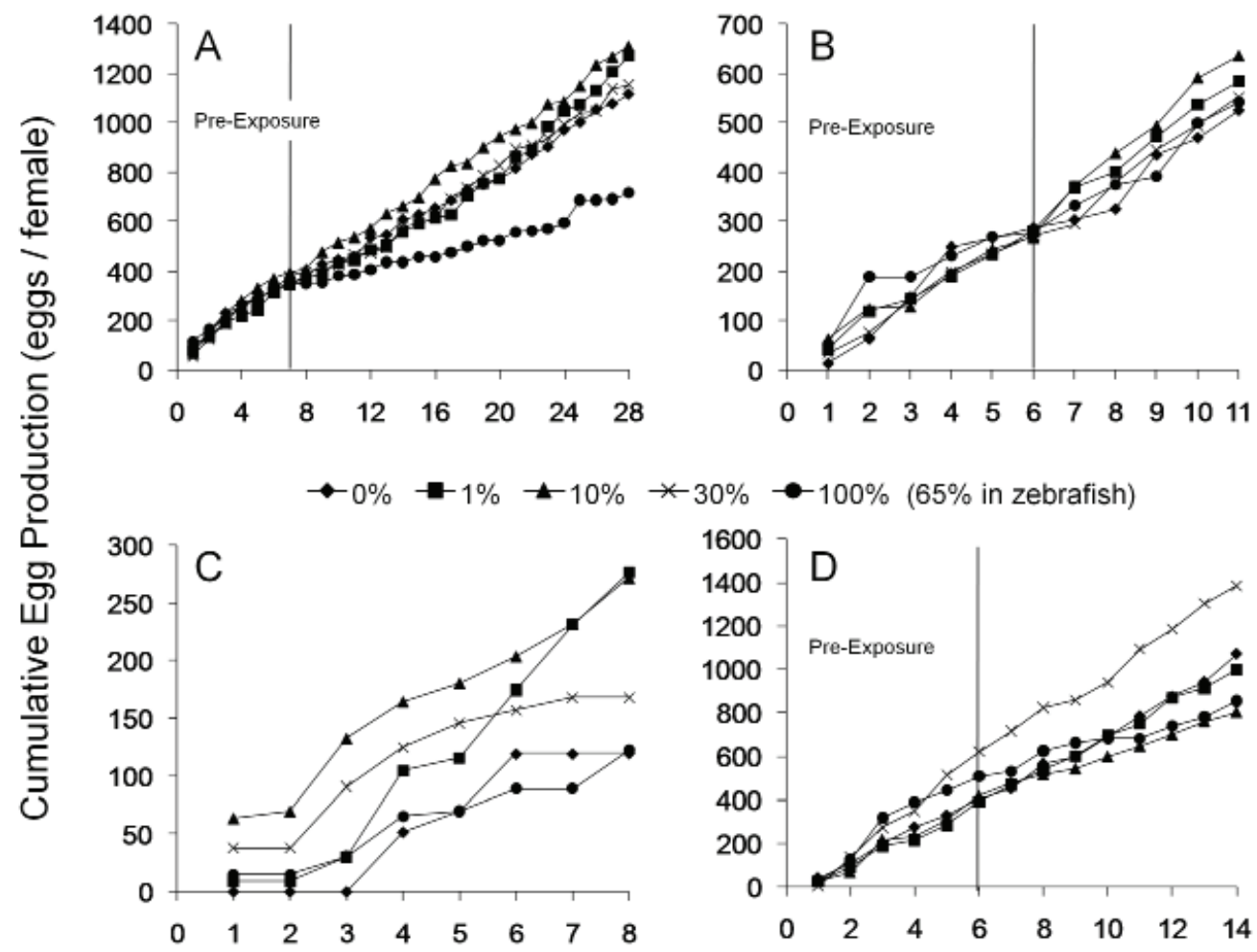

\section{Exposure Day}

Fig. 1. Cumulative egg production in A) the fathead minnow medium-term test, B) the fathead minnow short-term test, C) the mummichog reproduction test, and D) the zebrafish reproduction test. 


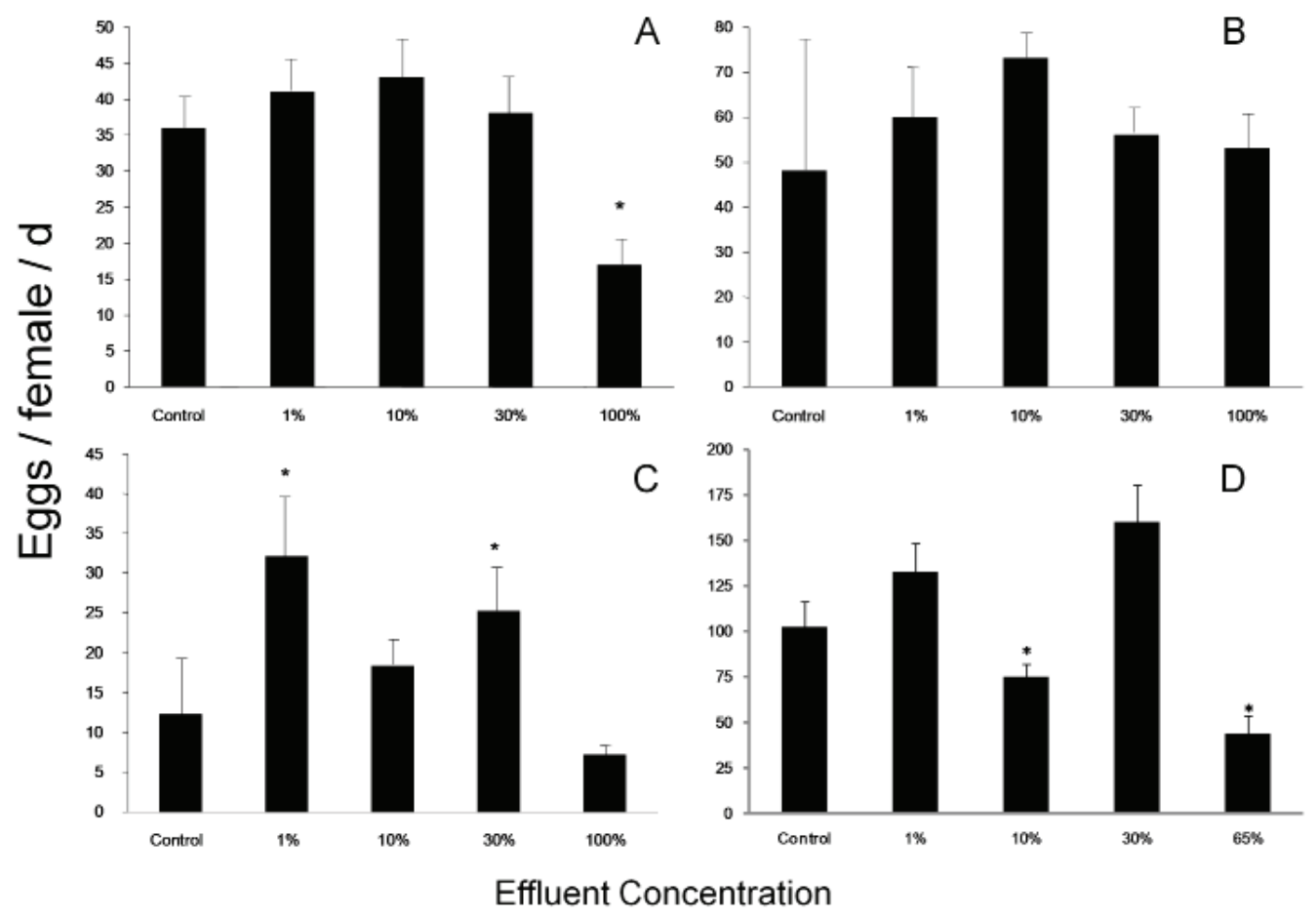

Fig. 2. Mean egg production per female per day in A) the fathead minnow medium-term test, B) the fathead minnow short-term test, C) the mummichog reproduction test, and D) the zebrafish reproduction test. Error bars indicate the standard error of the mean and asterisks represent significant differences from the control group.

effluent did not significantly affect the number of spawns or the percentage of egg fertilization (range 63 to $80 \%$ ) or hatching success (range 56 to $74 \%$ ). Gonad size in treatments was not significantly different from controls as measured at the end of the exposure. Secondary sex characteristics of fathead minnows were assessed and ratings for overall colouration of males were found to be significantly reduced by exposure to $100 \%$ effluent. On a scale of zero to five, control fish were rated as 2.8 \pm 0.16 (mean \pm the standard error of the mean [SEM]) and fish at $100 \%$ effluent were rated as $2.3 \pm 0.18$. The difference was attributed to lighter banding. In females, the ovipositor length was significantly shorter in the $100 \%$ treatment group (control fish: $4.0 \pm 0.13 \mathrm{~mm}$; $100 \%$ effluent fish: $3.3 \pm 0.16 \mathrm{~mm}$ ). In males, the number of tubercles, dorsal fin spot, and dorsal pad size were unaffected by effluent.

In the short-term fathead minnow exposure conducted in September 2006, effluent concentration did not significantly affect egg production (Fig. 1 and 2). In this test, egg fertilization rates were significantly lower in the $10 \%(58 \%)$ and $100 \%(68 \%)$ effluent as compared with the controls $(90 \%)$.

Egg production in mummichog showed a different pattern of effects as compared with fathead minnows. There were statistically significant increases in egg production at the 1 and $30 \%$ effluent concentrations (Fig. 1). There were no significant changes in gonad size since it covaries with body weight at the end of the exposure. Larvae hatched from those treatments and raised for six weeks in their respective effluent concentrations showed no significant differences in time to hatch (range 11 to $13 \mathrm{~d}$ ) or survival over this period (range 74 to $100 \%$ ).

In zebrafish, the pattern of egg production was similar to that in the 21-d fathead minnow bioassay and was reduced in the $65 \%$ effluent exposure, but also in the $10 \%$ exposure (Fig. 1 and 2). A reduced spawning rate coinciding with the reduction in egg production was also apparent in the $65 \%$ effluent tanks; preexposure testing had $71 \%$ of tanks containing eggs after spawning, whereas after effluent exposure began, only $33 \%$ of tanks, the lowest rate of the test, contained eggs each day in the $65 \%$ effluent exposure.

Biochemical indicators of exposure were measured in three species: threespine stickleback, fathead minnow, and rainbow trout (Table 2). Results show that the effluent was a weak inducer of CYP1A, as measured by EROD in both rainbow trout and stickleback, though this latter observation only held for one of the two timepoints. Examination of VTG as measured directly by ELISA in trout and fathead minnow, and by mRNA transcripts in stickleback, consistently showed no significant elevation in response to exposure to this effluent. The only androgen-linked endpoint examined was the expression of spiggin in stickleback. As with the stickleback EROD data, this endpoint was significantly elevated at $21 \mathrm{~d}$ but not at $7 \mathrm{~d}$.

Steroidogenesis and related endpoints were examined in a number of the reproductive and reproductiveendocrine bioassays (Table 3). In the fathead minnow 21-d bioassay, there were no differences in whole body sex steroids in males or females. The only difference observed in the mummichog reproductive endocrine bioassay plasma steroids was a significant depression 
Reproductive Bioassays for the Effects of BKME

TABLE 2. Mean (SEM, $n$ ) biochemical indicators of exposure to CYP1A inducers, estrogens, and androgens ${ }^{a, b, c}$

\begin{tabular}{|c|c|c|c|c|}
\hline \multirow{2}{*}{ Species and endpoint } & \multicolumn{4}{|c|}{ Relative change at effluent concentration (vol/vol) } \\
\hline & $1 \%$ & $10 \%$ & $30 \%$ & $100 \%$ \\
\hline \multicolumn{5}{|l|}{$\overline{C Y P 1 A}$} \\
\hline Rainbow trout EROD $7 \mathrm{~d}$ & ND & $1.80(0.33,9)$ & $4.15(0.68,9) *$ & $5.63(1.01,8) *$ \\
\hline Stickleback EROD males 7d & $2.18(0.01,11)$ & $0.42(0.13,8)$ & ND & $1.06(0.39,7)$ \\
\hline Stickleback EROD females $7 \mathrm{~d}$ & $1.01(0.30,7)$ & $1.00(0.26,7)$ & ND & $3.26(1.27,9)$ \\
\hline Stickleback EROD males $21 \mathrm{~d}$ & $1.81(0.22,11)$ & $10.5(4.02,6) *$ & ND & $7.27(1.55,5) *$ \\
\hline Stickleback EROD females $21 \mathrm{~d}$ & $1.71(0.78,6)$ & $1.78(0.14,9) *$ & ND & $5.25(1.49,9) *$ \\
\hline \multicolumn{5}{|l|}{ Estrogen - VTG } \\
\hline Rainbow trout $7 \mathrm{~d}$ & $1.00(0.02,8)$ & $1.03(0.04,8)$ & $1.03(0.03,8)$ & $1.25(0.23,8)$ \\
\hline Fathead minnow $21 \mathrm{~d}$ & $0.34(0.13,8)$ & $1.46(1.09,8)$ & $0.96(0.86,8)$ & $5.72(5.18,8)$ \\
\hline Stickleback $7 \mathrm{~d}$ & $0.91(0.17,8)$ & $1.00(0.25,8)$ & ND & $0.63(0.13,6)$ \\
\hline Stickleback $21 \mathrm{~d}$ & $0.76(0.27,8)$ & $0.54(0.48,8)$ & ND & $0.77(0.27,8)$ \\
\hline \multicolumn{5}{|l|}{ Androgen - Spiggin } \\
\hline Stickleback $7 \mathrm{~d}$ & $1.50(0.35,7)$ & $4.26(1.72,8)$ & ND & $4.03(2.16,7)$ \\
\hline Stickleback $21 \mathrm{~d}$ & $4.02(1.73,8)$ & $6.68(2.82,6) *$ & ND & $35.0(20.2,8) *$ \\
\hline
\end{tabular}

${ }^{a} \mathrm{ND}=$ no data.

${ }^{b}$ All endpoints are represented as fold-change relative to the control value $(0 \%=1.00)$.

${ }^{c}$ Asterisks (*) indicate significant differences with regard to the control treatment values.

in 11-ketotestosterone in males exposed to $1 \%$ effluent. In stickleback no significant exposure-related differences were found in in vitro steroid production measured by testosterone production in gonads from males and females, in estradiol production in ovaries, or in 11-ketotestosterone production in testes (data not shown, see Wartman et al. 2009). In zebrafish, there were no significant differences in in vitro sex steroid hormone production in females and mRNA transcripts of three key genes for steroidogenesis: StAR, 3 $\beta$-HSD, and P450arom were not influenced by the effluent exposure.

Lyophilized effluent extracts showed that AR and SSBP binding activity were predominantly in the dichloromethane extract. As levels in the methanol extract were on average only $6 \%$ of what was found, the first sequential extraction for both AR and SSBP bioassays, only the dichloromethane extract data is presented (Fig. 3). Levels of testosterone equivalents as measured by AR binding and SSBP varied substantially over the sampling period and ranged between 75 and $600 \mathrm{ng} / \mathrm{L}$. AR and ER binding were assessed independently on the single sample of effluent that was used for the stickleback bioassays. Rainbow trout brain AR binding for a variety of chemical extraction techniques ranged from 189 to $276 \mathrm{ng} / \mathrm{L}$ as testosterone equivalent concentrations, while rainbow trout liver estrogen receptor binding ranged from 53 to $93 \mathrm{ng} / \mathrm{L}$ as estradiol equivalent concentrations. SPME chemical profile ratios for the four sampling periods (normalized to the lowest total peak area) illustrate the variability in effluent strength since these were 3.3, 3.1, 3.5, and 1.0 for the May 30, June 16, July 13, and September 5, 2006 effluent samples, respectively.

TABLE 3. Mean (SEM, $n$ ) in vivo and in vitro testosterone (T), estradiol (E2), and 11-ketotestosterone (11-KT) production and expression of mRNA related to steroid hormone production ${ }^{a, b}$

\begin{tabular}{|c|c|c|c|c|c|}
\hline \multirow{2}{*}{ Species and endpoint } & \multicolumn{5}{|c|}{ Effluent concentration (vol/vol) } \\
\hline & $0 \%$ & $1 \%$ & $10 \%$ & $30 \%$ & $100 \%(65 \%)$ \\
\hline \multicolumn{6}{|l|}{ Whole body steroids } \\
\hline Fathead $\mathrm{T}$ in males $(\mathrm{ng} / \mathrm{g})$ & $1.77(0.34,8)$ & $1.35(0.47,8)$ & $0.99(0.16,8)$ & $1.17(0.24,8)$ & $2.12(0.67,8)$ \\
\hline Fathead $T$ in females (ng/g) & $1.21(0.17,8)$ & $1.10(0.14,8)$ & $1.62(0.27,8)$ & $2.07(0.60,8)$ & $1.93(0.38,8)$ \\
\hline Fathead E2 in females (ng/g) & $4.32(0.69,8)$ & $5.67(0.82,8)$ & $4.72(0.80,8)$ & $6.02(0.90,8)$ & $6.91(1.26,8)$ \\
\hline \multicolumn{6}{|l|}{ Plasma steroids } \\
\hline Mummichog $\mathrm{T}$ in males $(\mathrm{ng} / \mathrm{mL})$ & $0.70(0.29,12)$ & $0.22(0.01,12)$ & $0.39(0.11,12)$ & $0.34(0.01,12)$ & $0.36(0.01,12)$ \\
\hline Mummichog $11-\mathrm{KT}$ in males $(\mathrm{ng} / \mathrm{mL})$ & $1.51(0.21,12)$ & $0.60(0.08,12) *$ & $0.97(0.26,12)$ & $0.73(0.11,12)$ & $1.10(0.23,12)$ \\
\hline Mummichog $\mathrm{T}$ in females $(\mathrm{ng} / \mathrm{mL})$ & $0.71(0.16,11)$ & $0.74(0.16,11)$ & $0.52(0.04,11)$ & $0.46(0.04,11)$ & $0.48(0.38,11)$ \\
\hline Mummichog E2 in females $(\mathrm{ng} / \mathrm{mL})$ & $3.44(0.55,11)$ & $3.39(0.51,11)$ & $3.95(0.77,11)$ & $3.74(0.02,11)$ & $3.12(0.45,11)$ \\
\hline \multicolumn{6}{|c|}{ Steroidogenic gene expression and in vitro steroid production } \\
\hline Zebrafish $\mathrm{T}$ in females (ng/pg tissue) & $3.51(0.76,6)$ & $4.63(0.85,9)$ & $3.49(0.52,7)$ & $3.41(0.61,10)$ & $2.08(0.20,6)$ \\
\hline Zebrafish E2 in females ( $\mathrm{ng} / \mathrm{pg}$ tissue) & $6.38(0.71,6)$ & $8.64(1.33,8)$ & $7.09(1.66,7)$ & $4.74(0.72,10)$ & $3.96(1.16,7)$ \\
\hline Zebrafish StAR & $1.00(0.32,9)$ & Not tested & $0.57(0.14,10)$ & Not tested & $0.37(0.16,11)$ \\
\hline 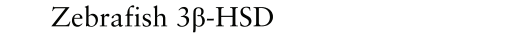 & $1.00(0.39,9)$ & Not tested & $0.99(0.27,10)$ & Not tested & $1.32(0.22,11)$ \\
\hline Zebrafish P450-arom & $1.00(0.35,9)$ & Not tested & $0.82(0.30,10)$ & Not tested & $1.46(0.80,11)$ \\
\hline
\end{tabular}

${ }^{a}$ Zebrafish mRNA endpoints were measured at $65 \%$ effluent in place of $100 \%$, are normalized to $\beta$-actin, and are represented as foldchange relative to the control value $(0 \%=1.00)$.

${ }^{b}$ Asterisk (*) indicates significant difference with regard to the control treatment value. 


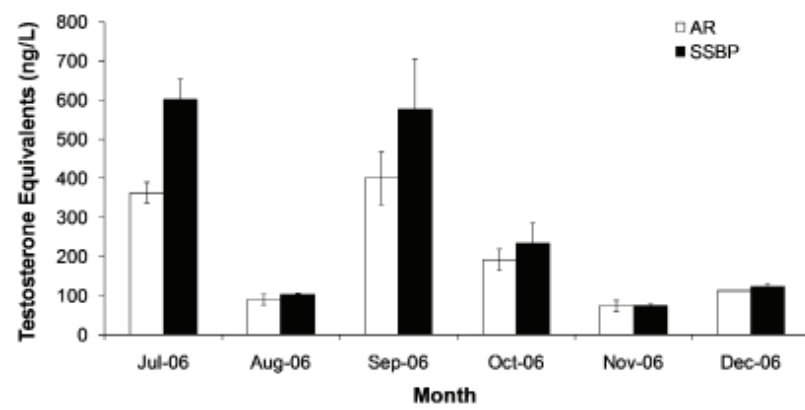

Fig. 3. Goldfish testes androgen receptor binding and goldfish sex steroid binding protein binding of La Tuque effluent extracts over the course of the studies. Error bars indicate the standard error of the mean.

\section{Discussion}

This study demonstrated that a Canadian bleached kraft mill effluent previously associated with reproductive effects in wild fishes had little or no impact on reproductive endpoints as measured using a number of laboratory bioassays. Reduction in egg production only occurred with $65 \%$ or full strength effluent. The reduction in egg production was not associated with alterations in steroidogenic endpoints measured in four different bioassays. In vitro receptor binding measurements of effluent extracts and induction of the spiggin gene indicated some exposure to androgens. Stickleback and rainbow trout bioassays also indicated exposure to CYP1A-inducing compounds. All of the bioassays employed consistently showed that this effluent had only a weak ability to cause reproductive effects and only at effluent concentrations well above those in the receiving environment.

A key objective of this study was to determine if laboratory short- and medium-term reproductive bioassays could predict effects observed in wild fish studies or in full life cycle studies. Evaluation of white sucker populations in the receiving environment concurrently with these studies showed that the effluent examined did not cause reductions in gonad size in white sucker captured in the receiving environment (Parrott et al. 2010). However, a reduction in circulating testosterone in males was observed in white sucker captured in the receiving environment of this mill. The results presented here in combination with accompanying work (Parrott et al. 2010) demonstrate that the La Tuque effluent at the time tested does not fit with the national response pattern of metabolic disruption (Lowell et al. 2005).

Effects in the effluent receiving environment of this bleached kraft mill have been the subject of scientific scrutiny for several decades. While initial studies of reproductive effects in wild fish were inconclusive (Hodson et al. 1992), subsequent studies showed that white sucker downstream of the mill were older and larger at maturity and female sucker had significantly reduced gonad development as compared with reference locations (Gagnon et al. 1995). These results were associated with reductions in steroid hormones in females (Gagnon et al. 1994). An additional endocrine effect, the inability of yellow perch (Perca flavescens) and northern pike (Esox lucius) to respond to artificial stress due to structural impairment of adrenal cells was also observed at this time (Hontela et al. 1997).

In addition to these studies, the fish of the St. Maurice River were assessed as part of the Canadian EEM program. During the first cycle of EEM, the mill switched to chlorine dioxide bleaching and a biological treatment plant was installed. These and other subsequent improvements led to a $98 \%$ decrease in BOD, a $91 \%$ decrease in suspended solids, and a $57 \%$ reduction in water usage from 1990 to 2002 (Smurfit-Stone 2002). Despite these improvements, reduced gonad size in female white sucker continued to be evidenced during the first three cycles of the EEM program (Lowell et al. 2005). This and accompanying studies (Parrott et al. 2010; Wartman et al. 2009) represent the first evidence that this mill no longer causes reproductive effects in fishes.

The life cycle test with fathead minnow conducted concurrently with the present short-term tests also showed the limited potency of this effluent to cause reproductive effects (Parrott et al. 2010). In that study, significant increases in egg production were seen at 1 and $30 \%$ effluent concentrations, and there was no significant decrease in egg production at $100 \%$ effluent as was observed in the fathead minnow medium-term test in the present study. The discrepancy between these results and the zebrafish and fathead minnow medium-term bioassay presented here can likely be explained by variability in effluent quality. The shorter bioassays were conducted during a period of normal operation following a mill shutdown in May, and effluent chemical profiling presented herein indicated that the effluent used in the bioassays conducted in June 2006 had a higher extractable organic content. This was confirmed by the short-term fathead minnow bioassay conducted in September when the effluent was lower in extractable organic content as determined by the chemical extractives profile and in which no reproductive effects were observed. The temporal variability in effluent quality was further indicated by significant fluctuations in a number of other chemical endpoints monitored during the lifecycle study (Parrott et al. 2010) and in the levels of testosterone equivalents from receptor binding assays. High variability in effluent quality has been previously demonstrated with long-term monitoring at other mills and is related to the complex nature of the mill process and treatment operations (van den Heuvel et al. 2010). Such variability represents a significant hurdle for conducting any reproductive or IOC studies with pulp and paper effluent. This underscores the need to understand the current status of mill operations before initiating studies, but also points to the need to conduct replicate experiments with effluents - thus short practical bioassays are essential for IOC work. This observation also provides evidence that minimization of perturbations 
leading to treatment system disequilibrium will be critical to the elimination of effects. This observation is consistent with our understanding that releases of substances to the treatment system via spills and condensate handling are a primary cause of reproductive dysfunction in exposed biota (Hewitt et al. 2008).

The observations presented herein demonstrate the conflict between selecting bioassays that are relevant to the primary observation in the field-reduced gonad size-while being sufficiently short and practical for the purposes of IOC work. As a gonad size effect was not observed at the La Tuque mill (Parrott et al. 2010), the ability of laboratory bioassays to predict this effect could not be addressed by this component of the IOC studies. No differences in gonad size were observed in the fathead minnow and mummichog short- to mediumterm bioassays presented herein. However, it seems unlikely that gonadal growth could ever be a responsive endpoint in such short bioassays. Evidence from New Zealand indicated that gonad growth in rainbow trout could only be impacted when exposure was initiated before, and not during, gonadal recrudescence (van den Heuvel and Ellis 2002) and that it can take more than an entire reproductive cycle to manifest changes in gonad size due to altered energy intake (van den Heuvel et al. 2008). There is also the question of whether gonad growth in fractional spawners such as fathead minnow, mummichog, or zebrafish is representative of gonad growth in a synchronous spawner such as the white sucker. The only bioassay capable of identifying changes to gonad growth was the longer-term fathead minnow life-cycle bioassay that demonstrated elevated gonad size in both males and females exposed to $100 \%$ La Tuque mill effluent (Parrott et al. 2010). Given the primacy of the gonad growth endpoint in the EEM mandate that drives IOC, a medium-term gonadal recrudescence bioassay would be more appropriate as an intermediate step in the IOC process.

It can be concluded that wild fish studies and laboratory bioassays were consistent in demonstrating that at the time of testing, this effluent was not capable of eliciting reproductive effects in fishes at environmentally relevant concentrations. The lack of an effluent-related effect in the laboratory bioassays when there was no effect seen in wild fish provides confidence about the utility of the tests selected for study for IOC/IOS work. In previous studies, egg production was identified as one of the most sensitive reproductive responses to pulp mill effluent exposure (Kovacs et al. 1995; Rickwood et al. 2006a), and egg production has been reduced in fishes exposed to a variety of pulp mill effluents (Martel et al. 2004; Rickwood et al. 2006a, 2006b). While some of those studies occurred at mills where reduced gonad size was observed, these studies were not specifically designed to relate the two endpoints. At one of the mills studied, there was longstanding evidence over two decades of reduced gonad size in wild white sucker (Bowron et al. 2009), yet fathead minnow reproductive tests showed a stimulation of egg production at environmentally relevant concentrations (Rickwood et al. 2006a). The gonad size changes in fishes exposed in the receiving environment is a complex endpoint and may not only be responding to the direct effects of toxicants. For example, a recent study has shown carotenoid depletion in the ovaries associated with impaired reproductive steroidogenesis in fish exposed to pulp and paper mill effluent downstream of a New Zealand mill (Landman et al. 2008). As carotenoids are only made by plants, these changes are likely indirect due to an ecosystem shift from autotrophic to heterotrophic production. The mechanism contributing to reduced egg production in laboratory bioassays may be distinct from the presumed endocrine mechanism contributing to reductions in gonadal development as seen in wild fish. Recent studies have shown the potential for effluents to modulate neuroendocrine function (Basu et al. 2009) and thereby contribute to the rapid cessation of spawning often observed in fish laboratory reproductive tests.

While reproduction in fishes was not impacted by environmentally relevant concentrations of the effluent studied, biochemical indicators of exposure provided some clues as to bioactive agents in pulp and paper mill effluent. In early studies, when the mill did not yet have secondary effluent treatment and used molecular chlorine bleaching, white sucker in the St. Maurice River demonstrated elevated liver CYP1A activity as far as 95 $\mathrm{km}$ downstream of the mill (Hodson et al. 1992). The results presented here indicate that the current biologically treated La Tuque mill effluent still contains CYP1Ainducing compounds, but the effluent alone is unlikely to cause this effect in the receiving environment where the maximum effluent dilution is in the order of $1 \%$. Reduction or elimination of CYP1A induction in fishes has been previously observed to occur concurrently with recovery of reproductive parameters (van den Heuvel et al. 2010) or rapidly following cessation of exposure (Munkittrick et al. 1992).

Androgens in pulp and paper mill effluents have been a longstanding observation. One of the earliest studies of the endocrine disrupting potential of pulp and paper mill effluent observed masculinization of female mosquitofish (Howell et al. 1980). Since those studies, the presence of androgen endpoints have been observed in Scandinavian, New Zealand, and Canadian pulp and paper mills (Larsson et al. 2000; Ellis et al. 2003; Hewitt et al. 2000, 2005). While studies in the United States have implicated androstenedione and androstadienedione as androgenic factors (Jenkins et al. 2001), these compounds and a suite of androstane androgens could not be detected in the $\mathrm{La}$ Tuque mill effluent in samples taken over the course of this study (Wartman et al. 2009) or in other Canadian and New Zealand effluents (Bandelj et al. 2006). The significance of these observations, particularly as they relate to effects on fish gonad size, remains unclear at present.

An important requirement of IOC/IOS studies is the availability of cost-effective laboratory tests which can be used to track effluent quality resulting from 
toxicity reduction manipulations. In the context of the EEM program, the requirement is for tests that could be used to develop strategies that would eliminate the national pattern of metabolic disruption, most notably smaller gonads in wild fish. Tests in the laboratory can assess reproductive performance at various levels of biological organization ranging from the biochemical to the whole organism, such as actual egg production. Usually, biochemical or biomarker responses can be elicited in shorter periods of time and with less effluent requirements, and these are desirable traits for IOC/ IOS tests. However, it is difficult to conclusively link biochemical alterations observed in laboratory tests to observations on the condition of wild fish populations. Because the effort for remedial action by industry may be substantial, it is absolutely essential to make sure that any leads from IOC/IOS work will have the desired benefits. Hence the need for the extensive comparison of the responses of the available fish reproduction tests with responses from a fish lifecycle test exposed to the same effluent in the laboratory as well as to the condition of fish exposed to the same effluent in the wild. While it was not possible to directly address several aspects of the intended IOC work at the La Tuque mill, the evidence for the short- and medium-term tests utilized in this study is promising.

\section{Conclusions}

This study demonstrated that it is possible to make changes in the operating conditions of a kraft mill that result in improved effluent quality that is reflected in the reproductive performance of fish exposed in laboratory tests as well as in the condition of wild fish. The specific changes leading to this improvement remain to be elucidated in future studies. Since the improvements resulted from compliance with new effluent regulatory limits, this demonstrates the success and value of the regulations as well as the EEM program. The ability of a given mill's effluent to affect fish reproduction has been shown to be inconsistent, and can be influenced by certain operating conditions and mill shutdowns. This can be a complicating factor for IOC/IOS work that needs to be given due consideration in future studies and demonstrates the importance of close contact/cooperation with mill staff. At the same time, the variations in effluent quality resulting from the changes in specific mill operating conditions are providing valuable leads concerning mitigation strategies.

The egg production endpoints evaluated in this study were sufficiently sensitive to track changes in effluent quality, and this is strong confirmation for the utility of such tests in IOC/IOS work. While it was not possible to identify laboratory test(s) best suited for assessing specific effluent-related effects on the gonad size of wild fish, the laboratory tests selected for evaluation in this study all appear to have good potential for IOC/IOS work. Further studies are currently underway with mill effluents affecting gonad size in wild fish, and which will provide the full evaluation necessary for test selection and ultimately for progress on solutions for the pulp and paper sector.

\section{Acknowledgements}

The authors acknowledge the support of the staff at the Smurfit-Stone mill in La Tuque, Quebec, particularly Gerard Desbiens, for their willingness to participate in this project, for supplying effluent shipments in a timely manner, and for providing information about mill operating conditions. Paul Tessier, formerly with the Smurfit-Stone Head Office in Montreal, was instrumental with the initiation of the project. Significant contributions were also made by Suzanne Batchelor, Jim Bennett, Thijs Bosker, Chad Boyko, Steve Ellis, Sharon Gibbons, Melinda Hanson, Natacha Hogan, Jacquie Matsumoto, Valerie Naish, Wendy Paterson, Robert Ross, Christina Simpson, Ed Sverko, Gerald Tetreault, Ruth Vanderveen, Cheryl Wartman, Tatyana Yurchuk, and Kalida Zemri.

\section{References}

Ankley GT, Jensen KM, Kahl MD, Korte JJ, Makynen EA. 2001. Description and evaluation of a short-term reproduction test with the fathead minnow (Pimephales promelas). Environ. Toxicol. Chem. 6:1276-1290.

Bandelj E, van den Heuvel MR, Leusch FDL, Shannon N, Taylor S, McCarthy LH. 2006. Determination of the androgenic potency of whole effluents using mosquitofish and trout bioassays. Aquat. Toxicol. $80: 237-248$.

Basu N, Anh Ta C, Waye A, Mao J, Hewitt M, Arnason JT, Trudeau VL. 2009. Pulp and paper mill effluents contain neuroactive substances that potentially disrupt neuroendocrine control of fish reproduction. Environ. Sci. Technol. 43:1635-1641.

Bowron LK, Munkittrick KR, McMaster ME, Tetreault G, Hewitt LM. 2009. Responses of white sucker (Catostomus commersoni) to 20 years of process and waste treatment changes at a bleached kraft pulp mill, and to mill shutdown. Aquat. Toxicol. 95:117-132.

Ellis RJ, van den Heuvel MR, Bandelj E, Smith MA, McCarthy LH, Stuthridge TR, Dietrich DR. 2003. In vivo and in vitro assessment of the androgenic potential of a pulp and paper mill effluent. Environ. Toxicol. Chem. 22:1448-1456.

Gagnon MM, Dodson JJ, Hodson PV, Van Der Kraak G, Carey JH. 1994. Seasonal effects of bleach kraft mill effluent on reproductive parameters of white sucker (Catostomus commersoni) populations of the St. Maurice River, Quebec, Canada. Can. J. Fish. Aquat. Sci. 51:337-347.

Gagnon MM, Bussieres D, Dodson JJ, Hodson PV. 1995. White sucker (Catostomus commersoni) growth and sexual maturation in pulp mill-contaminated and reference rivers. Environ. Toxicol. Chem. 14:317-327.

Gibbons WN, Munkittrick KR. 1994. A sentinel monitoring framework for identifying populations responses to industrial discharges. J. Aquat. Ecosyst. Health 3:227237. 
Hewitt M, Kovacs T, Dube M, MacLatchy D, Martel P, McMaster M, Paice M, Parrott J, van den Heuvel MR, Van Der Kraak G. 2008. Altered reproduction in fish exposed to pulp and paper mill effluents: A review of the roles of individual compounds and mill operating conditions. Environ. Toxicol. Chem. 27:682-697.

Hewitt M, Schryer R, Pryce A, Belknap A, Firth B, Van Der Kraak G. 2005. Accumulation of hormonally active substances by wild white Sucker (Catostomus commersoni) exposed to effluents discharged to the Wabigoon River. Water Qual. Res. J. Can. 40:315-327.

Hewitt LM, Parrott JL, Wells KL, Calp MK, Biddiscombe S, McMaster ME, Munkittrick KR, Van Der Kraak GJ. 2000. Characteristics of ligands for the Ah receptor and sex steroid receptors in hepatic tissues of fish exposed to bleached kraft mill effluent. Environ. Sci. Tech. 34:4327-4334.

Hodson PV, McWhirter M, Ralph K, Gray B, Thiverge D, Carey JH,Van Der Kraak G, Whittle DM, Levesque M.C. 1992. Effects of bleached kraft mill effluent on fish in the St. Maurice River, Quebec. Environ. Toxicol. Chem. 11:1635-1651.

Hogan NS, Wartman CA, Finley MA, van der Lee J, van den Heuvel MR. 2008. Simultaneous determination of androgenic and estrogenic endpoints in the threespine stickleback (Gasterosteus aculeatus) using quantitative RT-PCR. Aquat. Toxicol. 90:269-276.

Hontela A, Daniel C, Rasmussen JB. 1997. Structural and functional impairment of the hypothalamo-pituitaryinterrenal axis in fish exposed to bleached kraft mill effluent in the St.Maurice River, Quebec. Ecotoxicology $6: 1-12$.

Howell WM, Black DA, Bortone SA. 1980. Abnormal expression of secondary sex characters in a population of mosquitofish, Gambusia affinis holbrooki: Evidence for environmentally-induced masculinization. Copeia 4:676-681.

Ings JS, Van Der Kraak G. 2006. Characterization of the expression of StAR and steroidogenic enzymes in zebrafish ovarian follicles. Mol. Reprod. Devel. 73:943954.

Jenkins R, Angus, RA, McNatt H, Howell WM, Kemppainen JA, Kirk M, Wilson EM. 2001. Identification of androstenedione in a river containing paper mill effluent. Environ. Toxicol. Chem. 20:1325-1331.

Kovacs T, Martel P, Ricci M. 2007. A shortened adult fathead minnow reproduction test developed for investigation of cause and investigation of solution work involving pulp and paper mill effluents. Water Qual. Res. J. Can. 42:91-100.

Kovacs TG, Gibbons JS, Tremblay LA, O’Connor BI, Martel PH, Voss RH. 1995. The effects of a secondary-treated bleached kraft mill effluent on aquatic organisms as assessed by short-term and long-term laboratory tests. Ecotoxicol. Environ. Safety 31:7-22.

Landman MJ, Taylor S, van den Heuvel MR. 2008. Carotenoid depletion and ovarian dysfunction in common bully exposed to a New Zealand pulp mill effluent. Aquat. Toxicol. 87:303-309.
Larsson DGJ, Hällman H, Förlin L. 2000. More male fish embryos near a pulp mill. Environ. Toxicol. Chem. 19:2911-2917.

Lowell RB, Ring B, Patershank G, Walker SL, Trudel L, Hedley K. 2005. National assessment of the pulp and paper environmental effects monitoring data: Findings from cycles 1 through 3. NWRI Scientific Assessment Report Series 5. National Water Research Institute, Burlington, Ontario, Canada.

MacLatchy DL, Gormley KL, Ibey REM, Sharpe RL, Shaughnessy KS, Courtenay SC, Dubé MG, Van der Kraak GJ. 2005. A short-term mummichog (Fundulus heteroclitus) bioassay to assess endocrine response to hormone active compounds and mixtures. In: Ostrander GK (ed.) Techniques in Aquatic Toxicology, Vol 2. CRC Press, New York.

Martel P, Kovacs T, Voss R. 2004. Survey of pulp and paper mill effluents for their potential to affect fish reproduction, p. 78-92. In: Borton DL, Hall TJ, Fisher RS, Thomas J (ed.), Pulp and Paper Mill Effluent Environmental Fate and Effects. DEStech Publications, Lancaster, Pennsylvania.

Munkittrick KR, Vander Kraak GJ, McMaster ME, Portt CB. 1992. Response of hepatic MFO activity and plasma sex steroids to secondary treatment of bleached kraft pulp mill effluent and mill shutdown. Environ. Toxicol. Chem. 11:1427-1439.

Munkittrick KR, Van Der Kraak GJ, McMaster ME, Portt CB, van den Heuvel MR, Servos MR. 1994. Survey of receiving-water environmental impacts associated with discharges from pulp mills. 2. Gonad size, liver size, hepatic EROD activity and plasma sex steroid levels in white sucker. Environ. Toxicol. Chem. 13:1089-1101.

Parrott JL, Hewitt LM, Kovacs TG, MacLatchy DL, Martel PH, Paice M, van den Heuvel MR, Van Der Kraak GJ, McMaster ME. 2010. Responses in a fathead minnow (Pimephales promelas) lifecycle test and in wild white sucker (Catostomus commersoni) exposed to a Canadian bleached kraft mill effluent. Water Qual. Res. J. Can. 187-200.

Rickwood CJ, Dube MG, Hewitt LM, Kovacs TG, Parrott JL, MacLatchy DL. 2006a. Use of paired fathead minnow (Pimephales promelas) reproductive test. Part 1: Assessing biological effects of final bleached kraft pulp mill effluent using a mobile bioassay trailer system. Environ. Toxicol. Chem. 25:1836-1846.

Rickwood CJ, Dube MG, Hewitt LM, Kovacs TG, MacLatchy DL. 2006b. Use of paired fathead minnow (Pimephales promelas) reproductive test. Part 2: Source identification of biological effects at a bleached kraft pulp mill. Environ. Toxicol. Chem. 25:1847-1856.

Smurfit-Stone. 2002. Environmental Report. Smurfit-Stone.

Tessier C, Lowell RB, Willsie A, Kaminski G. 2009. National assessment of Cycle 4 data from the pulp and paper environmental effects monitoring program. National Environmental Effects Monitoring Office, Environment Canada, Gatineau, Quebec. [Available online at http://www. ec.gc.ca/esee-eem/default.asp?lang=En\&n=2E689B7B-1]. 
van den Heuvel MR, Slade AH, Landman MJ. 2010. Summary of a decade of research on the effects of a New Zealand pulp and paper mill on reproduction in fishes. Water Qual. Res. J. Can. 123-135.

van den Heuvel MR, Landman MJ, Finley MA, West DW. 2008. Altered physiology of rainbow trout in response to modified energy intake combined with pulp and paper effluent exposure. Ecotox. Environ. Saf. 69:187198.

van den Heuvel MR, Ellis RJ. 2002. Timing of exposure to pulp and paper effluent influences the manifestation of reproductive effects in rainbow trout. Environ. Toxicol. Chem. 21:2338-2347.

van den Heuvel MR, Munkittrick KR, Stegeman JJ, Dixon DG. 1995. Second round interlaboratory comparison of hepatic ethoxyresorufin-O-deethylase activity in white sucker (Catostomus commersoni) exposed to bleached-kraft pulp mill effluent. Environ. Toxicol. Chem. 14:1513-1520.

Van Der Kraak, GJ, Munkittrick KR, McMaster ME, Portt CB, Chang JP. 1992. Exposure to bleached kraft pulp mill effluent disrupts the pituitary-gonadal axis of white sucker at multiple sites. Toxicol. Appl. Pharmacol. 115:224-233.

Wartman CA, Hogan NS, Hewitt LM, McMaster ME, Landman MJ, Taylor S, Kovacs TG, van den Heuvel MR. 2009. Androgenic effects of a Canadian bleached kraft pulp and paper effluent as assessed using threespine stickleback (Gasterosteus aculeatus). Aquat. Toxicol. 92:131-139.

Received: 22 December 2009; accepted: 4 May 2010. 